\title{
Update on therapy for superficial mycoses: review article part I
}

Atualização terapêutica das micoses superficiais: artigo de revisão parte I

\author{
Maria Fernanda Reis Gavazzoni Dias ${ }^{1}$ \\ Fred Bernardes-Filho \\ Regina Casz Schechtman ${ }^{4}$
}

\author{
Maria Victória Pinto Quaresma-Santos ${ }^{2}$ \\ Adriana Gutstein da Fonseca Amorim ${ }^{3}$ \\ David Rubem Azulay
}

Abstract: Superficial fungal infections of the hair, skin and nails are a major cause of morbidity in the world. Choosing the right treatment is not always simple because of the possibility of drug interactions and side effects. The first part of the article discusses the main treatments for superficial mycoses - keratophytoses, dermatophytosis, candidiasis, with a practical approach to the most commonly-used topical and systemic drugs, referring also to their dosage and duration of use. Promising new, antifungal therapeutic alternatives are also highlighted, as well as available options on the Brazilian and world markets.

Keywords: Antifungal agents; Dermatomycoses; Mycoses; Therapeutics; Tinea; Yeasts

Resumo: As infecções fúngicas superficiais dos cabelos, pele e unhas representam uma causa importante de morbidade no mundo. O tratamento nem sempre é simples, havendo dificuldade na escolha dos esquemas terapêuticos disponíveis na literatura, assim como suas possíveis interações medicamentosas e efeitos colaterais. A primeira parte do trabalho aborda os principais esquemas terapêuticos das micoses superficiais - ceratofitoses, dermatofitoses, candidíase - possibilitando a consulta prática das drogas tópicas e sistêmicas mais utilizadas, sua dosagem e tempo de utilização. Novas possibilidades terapêuticas antifungicas também são ressaltadas, assim como as apresentações disponíneis no mercado brasileiro e mundial.

Palavras-chave: Antifúngicos; Dermatomicoses; Leveduras; Micoses; Terapêutica; Tinha

Received on 19.07.2012.

Approved by the Advisory Board and accepted for publication on 20.12.2012

Study carried out at the Rubem David Azulay Institute of Dermatology - Santa Casa de Misericórdia do Rio de Janeiro (IDPRDA- SCMRJ) - Santa Casa da Misericórdia do Rio de Janeiro (IDPRDA-SCMRJ) - Rio de Janeiro (RJ), Brazil.

Financial Support: None

Conflict of Interest: None

PhD - Professor on the postgraduate course at the Rubem David Azulay Institute of Dermatology - Santa Casa de Misericórdia do Rio de Janeiro (IDPRDASCMRJ), and coordinator of the mycology department of the Brazilian Dermatology Society (BDS) - Rio de Janeiro (RJ), Brazil.

Postgraduate doctor at the Rubem David Azulay Institute of Dermatology - Santa Casa de Misericórdia do Rio de Janeiro (IDPRDA- SCMRJ) - Rio de Janeiro (RJ), Brazil.

Qualified dermatologista from the Universidade Federal Fluminense (UFF) - Niterói (RJ), Brazil.

PhD in dermatology from the University of London; coordinator of the postgraduate course in dermatology and head of the mycology department at the Rubem David Azulay Institute of Dermatology - Santa Casa de Misericórdia do Rio de Janeiro (IDPRDA- SCMRJ) - Rio de Janeiro (RJ), Brazil.

Master's degree, head of Dermatology at the Rubem David Azulay Institute of Dermatology - Santa Casa de Misericórdia do Rio de Janeiro (IDPRDA- SCMRJ)

- Professor on the postgraduate course of the Pontifical Catholic University of Rio de Janeiro (PUC-RJ); Professor at the Souza Marques Foundation and Federal University of Rio de Janeiro (UFRJ) - Rio de Janeiro (RJ), Brazil. 


\section{INTRODUCTION}

Superficial fungal infections of the hair, skin and nails are a major cause of morbidity in the world, particularly in the tropics, where heat and humidity provide the ideal conditions for the growth of fungi that cause cutaneous infections. ${ }^{1-3}$ Direct contact is sufficient to transmit the infection from a contaminated surface or host to another. Dermatophytoses are the most common causes of fungal infection in men, though candidiasis and pityriasis versicolor are also examples of major superficial mycoses. This review article focuses on the topical and systemic treatment of superficial mycoses. ${ }^{3,4}$

\section{SUPERFICIAL MYCOSES}

With superficial mycoses, fungi are confined to the epidermis and annexes, and rarely invade the dermis. In extremely rare cases, internal organs can also be affected. There are two categories: non-inflammatory and inflammatory, infections. ${ }^{1,2,5}$

\section{NON-INFLAMMATORY INFECTIONS}

They can cause slight inflammation:

PITYRIASIS VERSICOLOR: described by Eichstedt in 1846, it is a recurring chronic, superficial infection, caused by lipophilic fungi of the Malassezia type, which is commonly found on the scalp and skin, without clinical manifestations, like an opportunist, and which can be an aggravating factor in many cases of seborrheic dermatitis. The 3 kinds most commonly related to this disease are: $M$. furfur, $M$. globosa and $M$. sympodialis. ${ }^{6}$ Yeast produces dicarboxylic acids such as azelaic acid, which inhibits tyrosine kinase, resulting in hypopigmentation of the area involved, especially in individuals with dark skin, though hyperchromic or erythematosus lesions can also appear, hence the term versicolor. ${ }^{1,7,8}$ The disease is characterized by oval-shaped or round maculas in seborrheic areas. Factors such as immunosuppression, poor hygeine, sweating, malnutrition, heat and humidity, can provoke the transformation of saprophytic yeasts into a pathogenic or invasive, mycelial, form. The diagnosis is clinical but it can be confirmed by detecting hyphae and spores following a direct examination using potassium hydroxide.

TINEA NIGRA/KERATOPHYTOSIS NEGRA: Produced mainly by hortae werneckii (formerly exophiala werneckii), and by stenella araguata, it occurs more commonly in female children in tropical and subtropical zones. ${ }^{2}$ Clinically, it is characterized by small unilateral, black patches that appear on palmar skin or, more rarely, on plantar skin and the edges of fingers. There can be a single lesion or a few that coalesce. Differential diagnosis is carried out with lentigo or melanoma and athlete's purpura. ${ }^{10-13}$

\section{PIEDRAS: There are 2 types:}

BLACK PIEDRA: caused by the fungus piedraia hortae, which is more common in tropical countries, characterized by black concretions in scalp hair..$^{14,15}$

WHITE PIEDRA: caused by the fungus trichosporom $s p$, occurring more in temperate climates, involving the appearance of white or light brown nodules that are loosely attached to axillary, pubic and facial, hair, as well as eyelashes..$^{14,16}$

They should be distinguished from pediculosis, monilethrix, trichorrhexis nodosa, trichomycosis and tinea capitis. ${ }^{1,2}$ The condition is also a common cause of onychomycosis in some Asian countries but several such cases have also been described in Brazil..$^{1,16}$

\section{INFLAMMATORY INFECTIONS DERMATOPHYTOSES}

These diseases are caused by a group of fungi that generally, in parasitic life, live at the expense of keratin of skin, hair and nails. The following fungi fall under this label: trichophyton, microsporum and epidermophyton, while T. rubrum is the most common agent. The superficial infection caused by the dermatophyte is called dermatophytosis and the term dermatomycosis refers to the infection from any of the fungi. ${ }^{4}$ Tinea is

a term used synonymously with dermatophytosis. Its prevalence is higher in tropical and subtropical zones, in regions with hot and humid climates. The infections are most commonly found in pre-adolescent children and can be endemic in developing countries. ${ }^{1,2.5}$ Dermatophytes can be classed as follows:

Anthropophylic: these fungi are found in humans and can cause epidemic infections, with little inflammation. They are transmitted from person to person or through fomites. ${ }^{1,2,14,16}$

Zoophilic: these fungi are found in animals and are transmitted to humans via direct or indirect contact, causing inflammatory and sometimes suppurative, dermatoses. . $^{1,2,14,16}$

Geophilic: these fungi originate in soil and infect humans sporadically via direct contact, bringing about inflammation. . $2,14,16^{2}$

Clinical diagnosis can be confirmed through microscopic examination or culture. Wood's light examinations are also a useful method, making hair appear in a fluorescent greenish color, in tinea favosa and tinea microsporica (trichophytic tinea does not become fluorescent). ${ }^{2.14}$ Several specific, clinical conditions can be described:

\section{TINEA CAPITIS}

There is an invasion of the hair follicle and surrounding skin, caused by trichophyton and microsporum. Hairs are broken close to the skin, producing tonsured areas, with small stumps of hair that are still 
implanted..$^{17,18}$ It can manifest clinically as:

Non-inflammatory dermatosis: caused by the ectothrix fungus (for instance, $M$. canis, the main organism in Brazil) or endothrix fungus, like T. tonsurans. ${ }^{17}$ In the case of trichophytic tinea, areas of hair loss are small, while black dots can appear, the blackish points located where hairs have been broken (exclamation mark hairs). It can evolve into pustular or kerion folliculitis. In microsporic tinea, the lesion is unique and large. Hairs return to normal with treatment or spontaneous involution. ${ }^{14,16}$

Folliculitis capitis abscedens et suffodiens: this is folliculitis with interconnecting tunnels and abscesses on the scalp. In general, the etiology is staphylococcal but, when mycotic, the most common agent is $T$. tonsurans, receiving the name perifolliculitis abscedens of Hoffman, described in 1956 by Ramos and Silva. ${ }^{1,2,14,16}$

Inflammatory dermatosis: most commonly caused by $T$. schoenleinii, termed tinea favosa, which evolves chronically, characterized by confluent, yellowish crusts (favus scutula) in large areas of the scalp. If left untreated, they can evolve into scarring alopecia. $1,2,14,16$

\section{TINEA CORPORIS}

This affects the stratum corneum of the glabrous skin, except for the palms, soles and groin. It can affect individuals of any age and the most common agents are $T$. rubrum and $T$. mentagrophytes. Typically, there are isolated or multiple erythematoussquamous, circinate lesions, in plaques, papules, vesicles or pustules, with centrifugal growth, in such a way that the external part is more active, that is to say, with a tendency to central healing. There is often itching and burning. If topical corticosteroids are used for presumptive diagnosis of eczema, there can be a change in the lesion (tinea incognito). When granulomatous infections occur, and with pustules around the follicles, it is called Majocchi granuloma. . 14,16,19,20,21 $^{2}$

\section{TINEA CRURIS}

The condition is most commonly found in patients with tinea pedis or onychomycosis, featuring autoinfection, and is more common in adult males. It is caused mainly by T. rubrum, E. Floccosum and T. mentagrophytes. Diabetes, obesity and sweating are predisposing factors. It is characterized by macerated, erythematous-squamous lesions, starting in the inguinal fold, which can spread to the thighs, perineum, buttocks, pubic region and lower stomach, typically avoiding the scrotum. It is very itchy and thus, lichenification is common..$^{21,22}$

\section{TINEA PEDIS AND TINEA MANUUM}

The coexistence of tinea pedis and tinea manuum is common. They are caused by T. rubrum, E. Floccosum, and T. mentagrophytes, though $T$. tonsurans can be isolated in children with tinea pedis. Tinea manuum presents as a scaly lesion on a palmar surface..$^{1,2,20,22}$ Tinea pedis can present clinically with lesions: ${ }^{1,16,20,22}$

Acute: caused by $T$. mentagrophytes var mentagrophytes. It is the eczematoid form, generally represented by plantar and digital vesicles, and is quite itchy.

Intertriginous: caused by T. mentagrophytes var interdigitalis, located in the interdigital folds, characterized by fissures and maceration.

Chronic: caused by T. rubrum, involving slightly itchy, scaly lesions, affecting practically the whole plantar region, appearing in "mocasin and/or glove" patterns, which are not necessarily symmetrical.

Athlete's foot can be caused by dermatophytes, candida and bacteria, which can act in isolation or association. It is characterized clinically by maceration, erythema, scaling and fissures. It is a first stage towards erysipelas. ${ }^{16,20}$

\section{TINEA UNGUIUM}

This is an infection of the nails from dermatophytes, caused mainly by the following dermatophyte fungi: T. rubrum, T. mentagrophytes var. interdigitale and E. floccosum. T. rubrum is almost always the agent of onychomycoses of fingers. ${ }^{1,222,23}$ The term onychomycosis means infection of the nails from dermatophytes or non-dermatophytes. Yeasts such as candida spp are well-known causing agents of onychomycoses, along with less common yeasts such as trichosporon spp. These fungi contaminate, though they can also bring about an active infection. It has been proven that these mushrooms invade the damaged keratin, causing onychomycosis, and in the case of scytalidium spp, they can invade healthy keratins. It affects men more frequently and is characterized by destructive and flaky lesions in nails, starting in the free margin and appearing in a white-yellowish color, similar to old ivory. Generally, there is keratosis of the nail bed. It is an eminently chronic disease, affecting one or several nails of the feet (typically of the hallux) or, less commonly, of the hands. Infection of the nails is generally secondary to plantar infection. ${ }^{22,23,24,25}$

They are classified clinically as follows: ${ }^{26}$

Distal and/or lateral subungual (the vast majority of cases): the most common agent is $T$. rubrum. These types are characterized by yellow distal onycholysis and subungual hyperkeratosis.

White superficial: caused by T. mentagrophytes, characterized by whitish discoloration of the nail plate. 
Proximal subungual and white superficial (generally caused by T. mentagrophytes). In chronic conditions, conditions can evolve with dystrophy.

In HIV-positive patients, the infection of nails is multiple and, most often, of the proximal subungual and white superficial type (through $T$ rubrum). Even if carried out properly, direct mycological exams often come back negative (there are indications that up to $60 \%$ can be false-negatives). When the result is positive, the culture is very often negative, requiring a repeat if doubts are strong. $1 ., 14,1,16,26$

\section{TINEA BARBAE}

Trichophytic sycosis: pustules appear in bearded areas and the moustache, with hairs in the middle. They can be isolated or form conglomerates. Evolution is generally chronic. ${ }^{1,2,3,4,14,16}$

\section{TINEA IMBRICATA (tokelau)}

It is a chronic variant of tinea corporis, caused by $T$. concentricum, and characterized by squamous lesions in concentric circles, which are very itchy and affect large areas of the body. It is endemic in certain parts of the world, for instance in Polynesia ("tokelau" ), and in Brazil (Mato Grosso and Amazônia), where it is called "chimberê". $13,14,16$

\section{CANDIDIASIS}

It is caused by Candida albicans (usually with saprophytes, in the gastrointestinal tube and vaginal mucous), and sometimes by other types of Candida ( $C$. parapsilosis, $C$. tropicalis, $C$. stellatoides etc.), affecting, in isolation or jointly, the mucosas, skin, nails and on occasion, other organs. It is of universal distribution, common in newborns, though it can also affect adults and elderly people. Some professionals, such as maids, dish washers, cooks and nurses, are more prone. Esophageal candidiasis and candidiasis of the upper airways are defining pathologies of AIDS. $1,3,14,16,20$ The clinical conditions are:

Oral candidiasis: it is more common in newborns and the elderly, debilitated patients and AIDS sufferers. Lesions are erosive and whitish in color.

Intertriginous candidiasis: it affects the natural folds (interdigital, inframammary, ungual, axillary) and is characterized by erosive, fissural, humid lesions, with a whitish, itchy coating, and by small, round, erythematous-squamous, satellite lesions, and even abacterial postules.

Ungual and periungual candidiasis: these infections entail intense erythematous-squamous, periungual lesions (paronychia), which are painful and can lead to onycholysis. Typically, they affect the proximal edge of the nail and appear mainly on fingernails, since they have the most contact with water.
Perleche (angular chelitis): this involves fissures at the corners of the mouth, which are common following changes in the architecture of the mouth following a prosthesis and thus, it is common in elderly people. There is also a high incidence in newborns (there have been suspicions of vaginal contamination). In general, there is bacterial association.

Vaginitis and balanitis: these infections involve erosive, whitish, humid and itchy lesions in the vagina and balanopreputial sulcus. Vaginal, whitish discharge, is characteristic. It does not occur in circumcised males. The infections can be acquired through sexual contact.

Chronic mucocutaneous candidiasis: this name is given to a heterogeneous group of clinical syndromes, often genetic, characterized by chronic and recurring infection of the skin, nails and oropharynx. There is no tendency to visceral dissemination or development. In general, it begins before the age of three and is characterized by oral lesions, perleche, ungual involvement and paronychia, with significant distrophy, vulvovaginitis and cutaneous impairment. In some cases, there can be keratotic lesions with a tendency to form cutaneous horns, or prominent granulomas that appear on the scalp, face, eyebrows and extremities.

\section{TREATMENT}

\section{PITYRIASIS VERSICOLOR}

Treatment for Pityriasis Versicolor (PV) can be carried out with a large number of agents, divided into two groups: topical and systemic. As regards topical agents, the most commonly used are selenium sulfide $(2.5 \%$ to $5 \%)$ in the form of shampoo used once a day; and ketoconazole shampoo (1 or $2 \%$ ). It should be used twice a week for 2 to 4 weeks; the mousse is left on the skin for around 10 minutes before being washed away. Patients with a high risk of reoccurrence can benefit from using ketoconazole shampoo once a week, in the same way as soap. Topical options include azoles/allylamines creams and lotions, propylene $50 \%$ in water, nystatin, salicylic acid and a great variety of anti-dandruff shampoos. In general, a new treatment is recommended after around 2 months, in order to avoid recurrence, which is frequent. All the topical "azoles" seem to be as effective as each other in treating PV. The use of loofah when showering is quite effective. Postinflammatory, pigmentary changes can respond to weak topical corticosteroids, but time is often needed for resolution. ${ }^{6,7,89,27}$

As regards systemic agents, the recommended dose for ketoconazole is $200 \mathrm{mg} /$ day for 10 days. Recovery rates are high (90-100\%). There is a risk of hepatotoxicity, estimated at 1:500.000 patients who take oral ketoconazole for a short period of time (10 
days). The recommended dose for fluconazole is $150 \mathrm{mg} /$ week for three weeks. The recommended dose for itraconazole is $200 \mathrm{mg}$ / day for seven days. It is a well-tolerated drug. In cases of recurrence, ketonazole $400 \mathrm{mg}$, fluconazole $300 \mathrm{mg}$ or itraconazole $400 \mathrm{mg}$, can be taken once a month orally as a prophylactic measure. Oral terbinafine is effective in combating many dermatophytoses, but not in treating PV, perhaps because it does not reach a sufficient concentration of the stratum corneum. Topical terbinafine has proven effective in treating infection from $M$. furfur. ${ }^{8,16,27}$

From a pharmacotherapeutic perspective, being a superficial infection, PV should be treated using topical agents. However, there are factors that undermine topical treatment and favor recurrence of the disease, including difficulties in applying the medication in large areas and the unpleasant smell of certain agents. The efficiency of topical agents is lower and recurrence rates vary between $60-80 \%{ }^{7.27}$ Systemic agents are recommended for short-term treatment of many patients, despite the side effects they can cause (Table 1). ${ }^{9}$

\section{TINEA NIGRA}

Since Tinea nigra (TN) is a superficial, asymptomatic mycosis, it can easily be eliminated through gathering flakes and/or friction during washing, and is often underdiagnosed. In some cases, scraping lesions with a curette can bring about their disappearance. Treatment can be carried out with topical keratolytics and imidazoles. The infection responds inconsistently to undecylenic acid, while tolnaftate is ineffective. ${ }^{10,13,28,29}$

\section{PIEDRAS}

For piedras on the scalp, removal using a fine comb is recommended in cases involving women. But the general rule is to carry out trichotomy on affected hair and use sublimate solution 1/1000 or even 1/2000 in $60 \%$ alcohol. For those who so wish, treatment can involve cologne, using the same amount of mercury bichloride, $0.3 \mathrm{~g}$ of sublimate solution for $300 \mathrm{ml}$ of cologne, or $600 \mathrm{ml}$, if the $1 / 2000$ proportion is chosen. ${ }^{18}$ Topical antifungals in the form of lotions or shampoos are often used, associated with exfoliating agents, to help prevent recurrence. Other options include mer-

TABLE 1: Systemic treatment of pityriasis versicolor

\begin{tabular}{lll}
\hline DRUG & DOSE & DURATION \\
\hline KETOCONAZOLE & $200 \mathrm{mg} /$ day & 10 days \\
FLUCONAZOLE & $150 \mathrm{mg} /$ week & 3 weeks \\
ITRACONAZOLE & $200 \mathrm{mg} /$ day & 7 days \\
\hline
\end{tabular}

cury bichloride $1 / 1000$ or $2 \%$ formaldehyde, which lead to good results, without the need to cut hair. Infections usually recur after treatment. 16,18,20

\section{DERMATOPHYTOSES \\ TINEA CAPITIS}

Oral treatment is necessary, since drugs need to penetrate hair follicles to be effective (Table 2). Preventive measures are important in managing the disease. As it is contagious, individuals living with infected patients should be examined and appropriately treated. The infection often begins through contact with animals, and treatment of the latter may be necessary. Chronicity can develop if children are continually re-exposed to untreated family members. ${ }^{13,16}$ The use of antifungal shampoos ( $2 \%$ ketoconazole $/ 2.5 \%$ selenium sulfide) or topical antifungal agents, can aid in the treatment, by eliminating fomites. Most studies mention that infected children do not need to miss school once treatment is started..$^{30,31,32}$

Griseofulvin is the only drug approved by the FDA (Food and Drug Administration) for treating tinea capitis, though the use of terbinafine, itraconazole and fluconazole is also reported extensively in medical literature. The effectiveness and safety profile of terbinafine, itraconazole and fluconazole are similar to those of griseofulvin, and these drugs can be used in case of therapeutic failure with griseofulvin. Dosages are normally based on weight and infections from Microsporum. It may be necessary to allow for higher dosages and more time, compared with infections from Trichophyton. ${ }^{33}$ Oral suspensions are available for griseofulvin, itraconazole and fluconazole, helping the treatment of children. Griseofulvin and terbinafine pills, as well as itraconazole capsules, can be crushed and added to food. ${ }^{34}$ In cases of inflammatory tinea capitis, the concomitant use of systemic corticosteroids can avoid or minimize scarring alopecia..$^{33,35}$

The dose suggested for griseofulvin, micronized formula, is $20-25 \mathrm{mg} / \mathrm{kg} /$ day, for $6-12$ weeks. With the ultra-micronized formula, a dose of $10-15 \mathrm{mg} / \mathrm{kg} /$ day is suggested, which is the most rapidly absorbed. The oral suspension (micronized griseofulvin) contains $125 \mathrm{mg}$ per $5 \mathrm{ml}$. Treatment should be continued for 2 weeks after clinical symptoms have cleared. Mycological cure rates are generally high, around $80-95 \%$ and $88-100 \%$, respectively. ${ }^{21,33}$

The terbinafine dose is based on the weight/250mg pill (under 20kg: $62.5 \mathrm{ml}$ or $1 / 4$ of a pill per day; $20-40 \mathrm{~kg}: 125 \mathrm{mg}$ or $1 / 2$ a pill per day; over $40 \mathrm{~kg}$ : $250 \mathrm{mg}$ or 1 pill per day). In general, treatment lasts for 4 weeks, though shorter periods have been reported..$^{31,32,33}$ Higher doses and/or longer duration might be necessary in cases of infection from M. canis. ${ }^{19,21}$ 
TABLE 2: Systemic treatment of tinea capitis

\begin{tabular}{|c|c|c|c|}
\hline DRUG & DOSE 21,35 & DURATION & COMPLETE CURE RATEA \\
\hline \multicolumn{4}{|l|}{ GRISEOFULVIN } \\
\hline Pill 500mg or & $\begin{array}{l}\text { *1- Micronized: } 20-25 \\
\text { mg/kg/day }\end{array}$ & 6-12 weeks & $\begin{array}{l}* 1-80-95 \% \\
* 2-88-100 \%\end{array}$ \\
\hline Suspension $125 \mathrm{mg} / 5 \mathrm{ml}$ & $\begin{array}{l}\text { *2-Ultramicronized: } 10-15 \\
\mathrm{mg} / \mathrm{kg} / \text { day }\end{array}$ & & \\
\hline \multicolumn{4}{|l|}{ TERBINAFINE $^{\mathrm{B}}$} \\
\hline Pill 250mg & $7 \mathrm{mg} / \mathrm{kg} /$ day & 6 weeks & $96 \%$ \\
\hline \multicolumn{4}{|l|}{ ITRACONAZOLEB } \\
\hline Pill 100mg or & $5 \mathrm{mg} / \mathrm{kg} /$ day & 6 weeks & $82-100 \%$ \\
\hline \multicolumn{4}{|l|}{ Suspension $10 \mathrm{mg} / \mathrm{ml}$} \\
\hline \multicolumn{4}{|l|}{ FLUCONAZOLE $^{\mathrm{C}}$} \\
\hline \multicolumn{4}{|l|}{ Pill } \\
\hline $\begin{array}{l}200 \mathrm{mg} \text { or } \\
\text { Suspension } 200 \mathrm{mg} / 5 \mathrm{ml}\end{array}$ & $8 \mathrm{mg} / \mathrm{kg} /$ week & 8 weeks & $98-100 \%$ \\
\hline
\end{tabular}

A: Cure with negative culture or microscopy

B: Not approved by the FDA (Food and Drug Administration) for children.

C: Not approved by the FDA to treat tinea capitis in children.

Itraconazole can be used to treat tinea capitis, although it has not been approved by the FDA for children. The therapeutic scheme is based around a continuous dosage of $5 \mathrm{mg} / \mathrm{kg} /$ day for 4 weeks, or pulsotherapy with a dose of $5 \mathrm{mg} / \mathrm{kg} /$ day for 1 week in the month, during 2-4 months. ${ }^{21}$

A small number of studies have shown that therapy with a fluconazole dosage of $6 \mathrm{mg} / \mathrm{kg} /$ day, lasting 2-3 weeks, can be effective in treating tinea capitis. ${ }^{19,21,30}$

The drugs used to treat tinea capitis can be classified into recommendation groups, according to the level of available scientific evidence (Table 3 ). ${ }^{32}$

Ia: Evidence obtained from a meta-analysis of randomized and controlled studies.

Ib: Evidence obtained from at least one randomized, clinical trial.

IIa: Evidence obtained from at least one controlled study without randomization.

IIb: Evidence obtained from at least one other type of quasi-experimental, defined study.

III: Evidence obtained from descriptive, nonexperimental, defined studies, such as comparative studies, correlation studies and case-control studies.

IV: Evidence obtained from clinical reports of committees, opinions or clinical experience, from respected authorities.

Oral, antifungal agents, including terbinafine, itraonazole and fluconazole, seem to have similar effectiveness rates and adverse effects to those of griseofulvin in children with tinea capitis, caused by types of trichophyton. Although they involve shorter treatment periods, they are more expensive (recommendation classification A, evidence force 1a). However, griseofulvin is the medication of choice for cases of tinea capitis caused by types of microsporum. It is more effective than terbinafine (recommendation classification $\mathrm{A}$; evidence force $1 \mathrm{~b}$ ); fluconazole (recommendation classification A; evidence force $1 b$ ) and itraconazole (recommendation classification A, evidence force $1 b)$.

\section{TINEA CORPORIS / CRURIS}

Topical treatment of localized tinea corporis can be effective, with imidazole cream such as isoconazole, tioconazole, econazole, ketoconazole and biconazole. Other topical agents used include sulfur tiocarbamates, like tolnaftate and tolciclate, ciclopirox olamine and terbinafine. These drugs, in 1\% cream, are used once or twice a day, during a period of 2-4 weeks. Dermatophytes do not respond to topical nystatin, unlike infections caused by candida. Topical treatment for tinea cruris should be carried out over 46 weeks. It is necessary to highlight the need to dry these areas thoroughly after washing and use postantifungals prophylactically. Cases brought about by Trichophyton rubrum often recur. In addressing extensive or inflammatory forms of tinea corporis and tinea cruris (common due to the use of preparations with corticoids), systemic treatment should feature, the drugs and doses for which are outlined in table $4 .^{20}$ 
TABLE 3: Hierarchization of recommendations

$\begin{array}{ll}\text { A (Levels of evidence IA, IB) } & \begin{array}{l}\text { Requires at least one controlled randomized trial as part of the literature, which is } \\ \text { of good general quality, consistent, and discusses the specific recommendation. }\end{array} \\ \text { B (Levels of evidence IIa, IIb, III) } & \begin{array}{l}\text { Demands the availability of well-conducted clinical studies, but there are no } \\ \text { randomized clinical trials on the topic. }\end{array} \\ \text { C (Level of evidence IV) } & \begin{array}{l}\text { Demands evidence from expert committee reports or opinions and/or clinical } \\ \text { experience of respected authorities. Indicates absence of quality, directly applicable } \\ \text { studies. }\end{array}\end{array}$

\section{TINEA PEDIS AND TINEA MANUUM}

The following topical treatments are recommended for non-inflammatory forms: isoconazole, tioconazole, econazole, ketoconazole and biconazole. Other topical products used include sulfur tiocarbamates, such as tolnaftate and tolciclate; ciclopirox olamine and terbinafine. These drugs, in 1\% cream, are used once or twice a day, during a period of 4-6 weeks. In cases of tinea pedis, when there is secondary infection, baths or compresses of potassium permanganate (1:10.000) and administration of antiobiotics like tetracyclines or macrolides, are also options. Later, if necessary, in the most inflammatory cases, systemic treatment can be applied, the drugs and doses for which are displayed in table 5. ${ }^{13,20}$

\section{TINEA UNGUIUM}

Onychomycoses can be difficult to treat and recurrence is common. Factors that contribute to recurrence include the lack of adaptation to treatment due to the high cost of medication, prolonged periods, inefficient use, the discontinuation of the medicine, resistance to the drug and side effects, such as hepatotoxicity and gastrointestinal manifestations. The success of the treatment depends as much on correct diagnosis and adequate prescription, as total adaptation to treatment from the patient, which often requires persistence and changes in habits. ${ }^{22}$

The therapeutic for onychomycoses currently involves three distinct treatments: topical therapy (including avulsion of the affected nail plate), systemic therapy and combined therapy. ${ }^{36,37}$

Topical therapy is recommended in cases where the nail matrix is not involved, when there are contraindications to systemic treatment, in white superficial onychomycosis and post-treatment prophylaxis. The advantage is the low level of systemic effect and drug interaction. ${ }^{37,38}$

Drugs used in topical treatment of onychomycoses include: 5\% amorolfine nail lacquer, $8 \%$ ciclopirox nail lacquer and $28 \%$ tioconazole solution. The ideal drug for topical treatment needs to have effective penetration and high concentrations in the nail plate. Studies have shown that $5 \%$ amorolfine and $8 \%$ ciclopirox in the form of nail lacquer penetrate the nail plate and reach the nail bed in higher concentrations than the minimum inhibitory concentration for most fungi that cause onychomycosis. ${ }^{37,38}$

Amorolfine is derived from morpholine and can be applied in many conditions, such as dermatophytes, yeasts and non-dermatophytic molds. It acts in two different enzymes involved in the biosynthesis of the ergosterol, modifying the morphology of hyphae, acting as a fungicide and fungistatic. ${ }^{39,40}$

Ciclopirox is recommended for dermatophytes, Candida sp, and some non-dermatophyte molds. It acts in different metabolic cell processes, especially in mitochondrias. Solutions and creams are not effective in treating onychomycoses. Amorolfine is recommended for weekly use, while $8 \%$ ciclopirox is recommended for daily use; some procedures involve taking this drug three times a week. Nail sanding should be carried out weekly in both cases. ${ }^{41}$

Nystatin in the form of cream, ointment, suspension or powder, is recommended for treating local infections caused by Candida $s p$ in the skin and mucosas, and can also be used in the topical treatment of paronychia. ${ }^{41}$

Chemical, mechanical or surgical avulsion are aimed at debriding the nail plate to reduce the critical fungal mass, allowing for a higher concentration and bio-availability of the drug in the deeper layers of the nails and nail bed. ${ }^{37,40}$

Mechanical abrasion of the nail bed can be applied with the help of a dermabrasor, using strips of sterilized sandpaper. Total surgical avulsion of nails is less common nowadays, due to the possibility of temporary or permanent distrophy of the plate, brought about by trauma in the nail matrix. Partial avulsion can be performed by removing the affected area. ${ }^{37,42}$

Systemic therapy is recommended in cases where the nail matrix is involved. It entails risks of drug interaction and collateral effects, though it is considered effective. The most-commonly used drugs in Brazil are griseofulvin, terbinafine, itraconazole and fluconazole. ${ }^{37,43,44}$ 
TABLE 4: Topical and systemic treatment of tinea corporis / cruris

\begin{tabular}{|c|c|c|c|c|}
\hline DRUG & TERBINAFINE & ITRACONAZOLEE & FLUCONAZOLE & KETOCONAZOLE \\
\hline $\begin{array}{l}\text { TINEA CORPORIS/ } \\
\text { CRURIS }\end{array}$ & $\begin{array}{l}{ }^{*}{ }^{C} \text { Cream }{ }^{A} \text { : applied } 1 \text { or } 2 \\
\text { times a day for } 1-4 \\
\text { weeks } \\
{ }^{*} 1 \% \text { solution }{ }^{A} \text { : applied } \\
1 \text { or } 2 \text { times a day for } 1 \\
\text { week } \\
{ }^{*} \text { Oral: } 250 \mathrm{mg} / \text { day for } \\
2-4 \text { weeks }\end{array}$ & $\begin{array}{l}{ }^{*} \text { Oral: } 200 \mathrm{mg} / \text { day for } \\
1 \text { week }\end{array}$ & $\begin{array}{l}{ }^{*} \text { Oral: } 150-300 \mathrm{mg} \text { once } \\
\text { a week for } 2-4 \text { weeks }\end{array}$ & $\begin{array}{l}* 2 \% \text { cream }^{A} \text { : applied } \\
\text { once a day for } 2 \text { weeks }^{*} \text { Oral }{ }^{A}: 200- \\
400 \mathrm{mg} / \text { day for } 4 \\
\text { weeks }\end{array}$ \\
\hline DRUG & GRISEOFULVIN & GRISEOFULVIN & $\begin{array}{l}\text { OTHER TOPICAL } \\
\text { DRUGS }\end{array}$ & $\begin{array}{l}\text { OTHER TOPICAL } \\
\text { DRUGS }\end{array}$ \\
\hline $\begin{array}{l}\text { TINEA CORPORIS/ } \\
\text { CRURIS }\end{array}$ & $\begin{array}{l}{ }^{*} \text { Micronized } \\
500 \mathrm{mg} / \text { day }^{\mathrm{A}} \\
{ }^{*} \text { Ultramicronized } 330- \\
375 \mathrm{mg} / \text { day for } 2-4 \\
\text { weeks }\end{array}$ & $\begin{array}{l}{ }^{*} \text { Micronized } \\
500 \mathrm{mg} / \text { day }^{\mathrm{A}} \\
{ }^{*} \text { Ultramicronized } 330- \\
375 \mathrm{mg} / \text { day for } 2-4 \\
\text { weeks }\end{array}$ & $\begin{array}{l}{ }^{*} \text { Ciclopirox } 0.77 \%{ }^{\mathrm{A}} \\
\text { cream and gel twice a } \\
\text { day for } 4 \text { weeks }\end{array}$ & $\begin{array}{l}{ }^{*} \text { Ciclopirox } 0.77 \%{ }^{\mathrm{A}} \\
\text { cream and gel twice a } \\
\text { day for } 4 \text { weeks }\end{array}$ \\
\hline
\end{tabular}

A: Approved by the FDA (Food and Drug Administration)

The antifungal activity of griseofulvin is attributed to the inhibition of the synthesis of the hyphal cell wall, effects on the synthesis of nucleic acid and inhibition of mitosis. It interferes in the microtubules of the mitotic spindle and cytoplasmic microtubules. The destruction of cytoplasmic microtubules can compromise the processing of recently-synthesized components of the cell wall in the extremities, in the growth of hyphae. Griseofulvin is only active against growing cells. The medicine is deposited in precursory keratin cells and thus, the drug is strongly linked to keratin and persists in it, making this substance resistant to fungal invasion. For this reason, nails that have recently grown are the first to heal. As keratin containing fungi is eliminated, it is replaced with normal tissue. ${ }^{41,44,45}$

Onychomycoses caused by yeasts do not respond to treatment with griseofulvin, while those caused by dermatophytes require prolonged administration. Nails on hands heal after about 6 months of treatment, whereas nails on feet are more resistant and can require 8-18 months of therapy. ${ }^{13,1,14,44}$

Azole derivatives are the most promising group in terms of antifungal therapy, as they combine strong effectiveness with a relatively low incidence of secondary side effects. There are two broad categories: imidazoles and triazoles, which have the same action mechanism and practically the same range of antifungal use. Systemic triazoles are metabolized more slowly and have less effect on human sterol synthesis than imidazoles. ${ }^{1,3,16,44}$

The main effect of azoles on fungi is the inhibition of sterol 14 alpha-demethylase, a microsomal enzyme system dependent on the cytochrome P450.
In this way, the biosynthesis of ergosterol in the cytoplasmic membrane is harmed, which leads to an accumulation of 14 alpha-methyl sterols and blocks the growth of fungi, since methyl sterols damage enzyme systems related to the membrane. ${ }^{41,44}$

Ketoconazole was the first widely applied antifungal ingested orally. It has a therapeutic effect on all superficial mycoses and on most deep, systemic and subcutaneous mycoses. It is available in cream, shampoo and pills. In the context of dermatophytoses, it retains a certain parallelism with griseofulvin. 41,4,46,47 $^{-1}$

The azoles itraconazole and fluconazole have had positive results in the treatment of ungual infections. Fluconazole is fungistatic, has good absorption, and involves little interaction, though its application range is limited (it is more effective against yeasts), and resistance to it is common. Some studies have shown that the use of oral itraconazole in treating ungual infections is effective. It is fungistatic, liposoluble and of wide application. In cases of onychomycoses, it has been used in pulsotherapy for a few months. Around $88 \%$ of patients treated are clinically and mycologically cured after nine months. ${ }^{1,3,16,20}$

Terbinafine is an allylamine that acts by inhibiting the squalene epoxidase enzyme in the cytoplasmic membrane of the fungus, leading to ergosterol deficiency and intracellular squalene accumulation. It is a fungicide for dermatophytes and yeasts (Tables 6 and 7). 1.,16,20,38,41

A recent study has demonstrated the effect of high frequency waves in the treatment of onychomycoses, and the ozone is generated with a fungicidal and bactericidal effect, stimulating circulation around 
TABLE 5: Topical and systemic treatment of tinea pedis / manuum

\begin{tabular}{|c|c|c|c|c|}
\hline & TERBINAFINE & ITRACONAZOLE & FLUCONAZOLE & KETOCONAZOLE \\
\hline \multirow[t]{3}{*}{$\begin{array}{l}\text { TINEA PEDIS/ } \\
\text { MANUUM }^{\mathrm{A}}\end{array}$} & $\begin{array}{l}{ }^{*} \mathrm{Cream}^{\mathrm{A}} \text { : applied } 1 \text { or } \\
2 \text { times a day for } 1-4 \\
\text { weeks }\end{array}$ & $\begin{array}{l}\text { *Oral: } 200 \mathrm{mg} 2 \text { times a } \\
\text { day for } 1 \text { week }\end{array}$ & $\begin{array}{l}\text { *Oral: } 150 \mathrm{mg} \text { once a } \\
\text { week for } 2-4 \text { weeks }\end{array}$ & $\begin{array}{l}{ }^{*} 2 \% \text { cream }^{\mathrm{A}} \text { : applied } \\
\text { once a day for } 6 \\
\text { weeks }\end{array}$ \\
\hline & $\begin{array}{l}{ }^{*} 1 \% \text { solution }{ }^{\mathrm{A}} \text { : applied } \\
1 \text { or } 2 \text { times a day for } 1 \\
\text { week }\end{array}$ & & & $\begin{array}{l}{ }^{*} \mathrm{Oral}^{\mathrm{A}}: 200 \\
400 \mathrm{mg} / \text { day for }>4 \\
\text { weeks }\end{array}$ \\
\hline & $\begin{array}{l}\text { *Oral: } 250 \mathrm{mg} / \text { day for } \\
2 \text { weeks }\end{array}$ & & & \\
\hline DRUG & GRISEOFULVIN & & TOPICAL DRUGS & \\
\hline \multirow{3}{*}{$\begin{array}{l}\text { TINEA PEDIS/ } \\
\text { MANUUM }^{\mathrm{A}}\end{array}$} & ${ }^{*}$ Micronized 1g/day ${ }^{\mathrm{A}}$ & & ${ }^{*}$ Ciclopirox $0.77 \%{ }^{\mathrm{A}}$ & \\
\hline & $\begin{array}{l}\text { *Ultramicronized } 660 \\
\text { or } 750 \mathrm{mg} / \text { day for } 4-8\end{array}$ & & $\begin{array}{l}\text { cream and gel twice a } \\
\text { day for } 4 \text { weeks }\end{array}$ & \\
\hline & weeks & & $\begin{array}{l}{ }^{*} \text { Antifungal powder for } \\
\text { prevention }\end{array}$ & \\
\hline
\end{tabular}

A: Approved by the FDA (Food and Drug Administration

the area of application, with a vasodilator and hyperemia function, facilitating the penetration of systemic medication. ${ }^{43}$

Propolis provides anti-inflammatory, healing, antitumor, antimicrobial, and above all antifungal, action. It is a resinous substance gathered from trees, produced by the bee Apis mellifera, containing innumerous agents, such as flavonoids. ${ }^{48}$

The combination of topical and systemic therapy can increase cure rates or even reduce treatment time, though there are no conclusive studies on this. It is recommended in the same way as systemic therapy and has the advantage of being more effective when compared to oral monotherapy, by allowing for a synergistic effect. Absolute indications for this therapeutic option are hyperkeratosis of the nail plate (thickness of over $2 \mathrm{~mm}$ ) and the total dystrophic form. Relative indications include: patient resistance to monotherapy treatment and the other forms of onychomycosis. The association of systemic medication should accord priority to drugs with different action mechanisms (eg: itraconazole or fluconazole + terbinafine), to be chosen in accordance with each case. ${ }^{37}$

Photodynamic therapy (PDT) has been applied

TABLE 6: Systemic treatment - hand nails

\begin{tabular}{lll}
\hline DRUG & DOSE & DURATION \\
\hline ITRACONAZOLE CONTINUOUS & $200 \mathrm{mg} /$ day & $6-12$ weeks \\
ITRACONAZOLE PULSE & $400 \mathrm{mg}$ day $/ 7 \mathrm{~d} /$ month & $2-3$ pulses \\
TERBINAFINE CONTINUOUS & $250 \mathrm{mg} /$ day & $6-12$ weeks \\
TERBINAFINE PULSE & $500 \mathrm{mg}$ day $/ 7 \mathrm{~d} / \mathrm{month}$ & $2-3$ pulses \\
FLUCONAZOLE & $150 \mathrm{mg} /$ week & Until clinically cured \\
GRISEOFULVIN & $500-1000 \mathrm{mg}$ & Until clinically cured \\
\hline
\end{tabular}

TABLE 7: Systemic treatment - foot nails

\begin{tabular}{lll}
\hline DRUG & DOSE & DURATION \\
\hline ITRACONAZOLE CONTINUOUS & $200 \mathrm{mg} /$ day & $12-24$ weeks \\
ITRACONAZOLE PULSE & $400 \mathrm{mg}$ day $/ 7 \mathrm{~d} / \mathrm{month}$ & $3-6$ pulses \\
TERBINAFINE CONTINUOUS & $250 \mathrm{mg} /$ day & $12-24$ weeks \\
TERBINAFINE PULSE & $500 \mathrm{mg}$ day $/ 7 \mathrm{~d} / \mathrm{month}$ & $3-6$ pulses \\
FLUCONAZOLE & $150-300 \mathrm{mg} /$ week & Until clinically cured \\
GRISEOFULVIN & $500-1000 \mathrm{mg}$ & Until clinically cured \\
\hline
\end{tabular}


TABLE 8: Systemic treatment of oral/vulvovaginal/balano-preputial candidiasis

\begin{tabular}{llll}
\hline DRUG & ITRACONAZOLE & FLUCONAZOLE & KETOCONAZOLE \\
\hline CANDIDIASIS & ${ }^{*}$ Oral: 200mg/ & ${ }^{*}$ Oral: 150mg & ${ }^{*}$ Oral: 200mg/day \\
ORAL/VULVOVAGINAL & day for 5 days & single dose & for 5-10 days \\
BALANO-PREPUTIAL & & & \\
\hline
\end{tabular}

TABLE 9: Systemic treatment of chronic mucocutaneous candidiasis

\begin{tabular}{ll}
\hline DRUG & GRISEOFULVIN \\
\hline CHRONIC & *Initial dose of $25 \mathrm{mg}$ and continue with $50 \mathrm{mg}$. Dilute in $500 \mathrm{ml}$ of $5 \%$ \\
MUCOCUTANEOUS & glucose solution, add $25 \mathrm{mg}$ of hydrocortisone succinate, apply IV, drop \\
CANDIDIASIS & by drop, with a duration of 6 hours, on alternate days. Total dosage of \\
& $1.5-3.0 \mathrm{~g}$. Do not use on patients with cardiac or renal dysfunctions.
\end{tabular}

recently, especially in patients presenting contraindications to the use of systemic antifungals. In vitro studies have shown that $T$. rubrum, a causing agent in approximately $90 \%$ of onychomycoses, is capable of metabolizing 5-aminolevulinic acid to protoporphyrin IX, and that PDT brings about significant reduction of its growth. It is slightly invasive and only active locally, with no damage to healthy tissue or collateral systemic effects. In addition, there are no reports of resistance from fungi and the lack of cumulative or mutagenic effects allows for repeated treatments. However, the discomfort reported by patients during illumination, as well as local phototoxic reactions (though transitory), render wide use of the method impossible. ${ }^{49}$

Interest is growing regarding new phototherapy technologies for the treatment of local bacterial and fungal infections. The Nd YAG laser (wavelength of $1064 \mathrm{~nm}$ ) has proven a promising option for treating onychomycoses and onychobacterioses. One of the main advantages of laser treatment is the bactericidal and fungicidal effect. Laser light provokes local hyperthermia, destruction of pathogenic microorganisms and stimulation of the reparation process. The success of the clinical use of lasers depends on the wavelength used, the exiting energy, pulse duration, exposure time, point size, type and color of the targeted tissue..$^{50}$

Experience in treating non-dermatophytic onychomycosis is still limited due to the variety of etiological agents potentially involved, its low frequency and the small number of reported cases in the literature. Treatment with terbinafine and itraconazole for three months can be considered effective in immunocompetent patients. ${ }^{23}$

In medical practice, clinical improvement in onychomycoses normally becomes apparent after the second or third month, but it has been noted that many patients end up abandoning treatment. This is under- standable, since onychomycosis provokes social limitations, and given the psychological impact of the unsightly appearance of the disease. There are also some situations that undermine clinical management, namely: sensitivity to antifungals, hepatoxicity, drug interaction and intolerance to prolonged therapeutics. ${ }^{46}$

\section{TINEA BARBAE/ TINEA IMBRICATA (tokelau)}

Treatment for tinea barbae is carried out with oral antifungals including terbinafine $250 \mathrm{mg}$ / day, fluconazole $150 \mathrm{mg}$ / week or itraconazole $100 \mathrm{mg}$ / day, for 2-4 weeks. Systemic corticoids are useful for intensely inflammatory lesions. ${ }^{20}$

Oral treatment using griseofulvin or terbinafine is effective against tinea imbricata, though recurrence is common. . $^{16,20}$

Topical treatment using imidazole creams can be performed as an adjuvant once or twice a day for 24 weeks, for both tinea barbae and tinea imbricata..$^{20}$

\section{CANDIDIASIS}

The first step is the elimination of predisposing factors. Gentian violet diluted in 1:10.000 aqueous solution, 10\% alcohol, can be used for oropharyngeal manifestations; and potassium permanganate solutions of $1 / 3.000$ to $1 / 5.000$. The best therapeutic for all forms is nystatin but it is not very effective when administered orally, unless it is for gastroenterital forms, as the medicine is not absorbed in the intestine. The oral dose can reach up to 1,500,000 daily units, distributed in 3 or 4 doses. To treat vaginitis, nystatin can be used in the form of vaginal cream, as well as vaginal imidazole creams. ${ }^{1,2,3,14,16}$

Systemic treatment should be applied for extensive forms, for which fluconazole, itraconazole and ketoconazole, can be used. In refractory cases, the use of amphotericin B is recommended. (Tables 8 and 9) ${ }^{1,3,14,16,20}$ 


\section{REFERENCES}

1. Verma S, Heffernan MP. Superficial fungal infection: dermatophytosis, tinea nigra, piedra. In: Fitzpatrick TB, Eisen AZ, Wolff K, Freedberg IM, Austen KF, editors. Dermatology in general medicine. 7th ed. New York: McGraw-Hill; 2008. p.1807-21.

2. Lacaz CS, Porto E, Martins JEC, Heins-Vaccari EM, Melo NT. Tratado de Micologia Médica Lacaz. 9 ed. São Paulo: Sarvier; 2002. p.252-340.

3. Hay RJ, Ashbee HR. Superficial mycoses. In: Burns T, Breathnach S, Cox N, Griffiths C, editors. Rook's Textbook of Dermatology. 8 th. Singapore: Wiley Blackwell; 2010. p. 36.5-36.68.

4. Degreef $H$. Clinical forms of dermatophytosis (ringworm infection). Mycopathologia. 2008;166:257-65.

5. Charles AJ. Superficial cutaneous fungal infections in tropical countries. Dermatol Ther. 2009;22:550-9.

6. Zaitz C, Ruiz LRB, Souza VM. Dermatosis associated with yeasts from Malassezia genus. An Bras Dermatol 2000;75:129-42.

7. Crespo Erchiga V, Delgado Florencio V. Malassezia species in skin diseases. Curr Opin Infect Dis. 2002;15:133-42.

8. Savin R. Diagnosis and treatment of tinea versicolor. J Fam Pract. 1996;43:127-32.

9. Oliveira JR, Mazocco VT, Steiner D. Pityriasis Versicolor. An Bras Dermatol. 2002;77:611-8

10. Diniz LM. Study of nine observed cases of Tinea Nigra in Greater Vitória (Espírito Santo state, Brazil) over a period of five years. An Bras Dermatol. 2004;79:305-10.

11. Araújo Gde M, Araújo ND, Farias RP, Cavalcanti FC, Lima Mdo L, Braz RA. Superficial mycoses in Paraíba: a comparative analysis and bibliographical revision. An Bras Dermatol. 2010;85:943-6.

12. Falabella R, Caplan RM. Cure of tinea nigra by epidermal stripping. Arch Dermatol. 1965;91:637-8

13. Mattos e Dinato SL, Almeida JRP, Romiti N, Camargo FAA. Tinea nigra in the City of Santos: five case reports. An Bras Dermatol. 2002;77:721-6.

14. Azulay RD, Azulay DR, Abulafia LA. Micoses superficiais. In: Azulay DR. Dermatologia. 5. ed. Rio de Janeiro: Guanabara Koogan; 2011. p.419-39

15. Oliveira JA, Barros JA, Cortez ACA, Oliveira JSRL. Superficial mycoses in the City of Manaus/AM between March and November/2003. An Bras Dermatol. 2006;81:238- 43.

16. Sobera JO, Elewski BE. Fungal diseases. In: Bolognia JL, Jorizzo JL, Rapini RP, editors. Dermatology. 2nd. New York: Mosby Elsevier; 2008. p.1135-49.

17. Fernandes NC, Akiti T, Barreiros MGC. Dermatophytoses in children: study of 137 cases. Rev Inst Med Trop Sao Paulo. 2001;43:83-5.

18. Carvalhaes Oliveira J. Tricomicoses nodulares. In: Carvalhaes Oliveira J. Micologia Médica. Rio de Janeiro: Control Lab, 1999. p.69-71.

19. Gürtler TGR, Diniz LM, Nicchio L. Tinea capitis micro-epidemic by Microsporum canis in a day care center of Vitória - Espírito Santo (Brazil). An Bras Dermatol. 2005;80:267-72.

20. Sampaio SAP, Rivitti EA. Micoses superficiais. In: Sampaio SAP, Rivitti EA, editores. Dermatologia. 3. ed. São Paulo: Artes Médicas; 2008. p.703-22.

21. Gupta AK, Cooper EA. Update in antifungal therapy of dermatophytosis. Mycopathologia. 2008;166:353-67.

22. Campanha AM, Tasca RS, Svidzinski TIE. Dermatomicoses: Frequência, diagnóstico laboratorial e adesão de pacientes ao tratamento em um Sistema Público de Saúde, Maringá-PR, Brasil. Lat Am J Pharm. 2007;26:442-8.

23. Araújo AJG, Bastos OMP, Souza MAJ, Oliveira JC. Onychomycosis caused by emergent fungi: clinical analysis, diagnosis and revision. An Bras Dermatol. 2003; 78:445-455.

24. Baran R, Kaoukhov A. Topical antifungal drugs for the treatment of onychomycosis: an overview of current strategies for monotherapy and combination therapy. $J$ Eur Acad Dermatol Venereol. 2005;19:21-9.

25. Sigurgeirsson B, Paul C, Curran D, Evans EG. Prognostics factors of mycological cure following treatment of onychomicosis with oral antifungal agents. $\mathrm{Br} J$ Dermatol. 2002;147:1241-3.

26. Hay RJ, Baran R. Onychomycosis: a proposed revision of the clinical classification. J Am Acad Dermatol. 2011;65:1219-27.

27. Zaitz C, Sampaio SAP. An evaluation of the effectiveness and torerability of intraconazole in the treatment of pityriasis versicolor. An Bras Dermatol. 1995;70:195-8.

28. Sayegh-Carreño R, Abramovits-Ackerman W, Girón GP. Therapy of tinea nigra plantaris. Int J Dermatol. 1989;28:46-8.

29. Giraldi S, Marinoni LP, Bertogna J, Abbage KT, Oliveira VC. Tinea nigra: six cases in Parana state. An Bras Dermatol. 2003;78:593-600.
30. Roberts BJ, Friedlander SF. Tinea capitis: a treatment update. Pediatr Ann. 2005;34:191-200.

31. Abdel-Rahman SM, Herron J, Fallon-Friedlander S, Hauffe S, Horowitz A, Rivière GJ. Pharmacokinetics of terbinafine in young children treated for tinea capitis. Pediatr Infect Dis J. 2005;24:886-91.

32. Kakourou T, Uksal U; European Society for Pediatric Dermatology. Guidelines for the management of tinea capitis in children. Pediatr Dermatol. 2010;27:226-8.

33. Haroon TS, Hussain I, Aman S, Jahangir M, Kazmi AH, Sami AR, et al. A randomized double-blind comparative study of terbinafine for 1,2 and 4 weeks in tinea capitis. Br J Dermatol. 1996;135:86-8.

34. Dastghaib L, Azizzadeh M, Jafari P. Therapeutic options for the treatment of tinea capitis: griseofulvin versus fluconazole. J Dermatolog Treat. 2005;16:43-6.

35. Loo DS. Systemic antifungal agents: an update of established and new therapies. Adv Dermatol. 2006;22:101-24.

36. Lecha M, Alsina M, Rodriguez JMT, Erenchun FR, Miranda A, Rossi AB. Anopenlabel multicenter study of the combination of amorolfine nail lacquer and oral itraconazole compared with oral itraconazole alone in the treatment of severe toenail onychomycosis. Curr Ther Res Clin Exp. 2002;63:366-79.

37. Ruiz LRB, Di Chiacchio N. Manual de conduta nas onicomicoses. Diagnóstico e tratamento. Sociedade Brasileira de Dermatologia. [acesso 10 jul 2012]. Disponível em: www.saudedireta.com.br/docsupload/1365643182manual-onicomicoses.pdf

38. Lecha M, Effendy I, Feuilhade de Chauvin M, Di Chiacchio N, Baran R; Taskforce on Onychomycosis Education. Treatment options --development of consensus guideline. J Eur Acad Dermatol Venereol. 2005;19:25-33.

39. Polak A. Kinetics of amorolfine in human nails. Mycoses. 1993;36:101-3.

40. Sidou F, Soto P. A randomized comparison of nail surface remanence of three nail lacquers, containing amorolfine $5 \%$, ciclopirox $8 \%$ or tioconazole $28 \%$, in healthy volunteers. Int J Tissue React. 2004;26:17-24.

41. Gilman AG, Molinoff PB, Hardman JG. Fármacos Antimicrobianos; Fármacos Antifúngicos. In: Hardman JG, Limbird LE, Molinoff PB, Ruddon RW, Gilman AG, editores. As bases Farmacológicas da Terapêutica: Goodman e Gilman. 9. ed. Santiago do Chile: Me Graw Hill; 1996. p.864-75.

42. Di Chiacchio N, Kadunc BV, de Almeida AR, Madeira CL. Nail abrasion. J Cosmet Dermatol. 2003;2:150-2.

43. Silva JL, Doimo G, Faria DP. The use of high frequency waves to treat onychomycosis: preliminary communication of three cases. An Bras Dermatol. 2011;86:598600.

44. Roberts DT, Taylor WD, Boyle J; British Association of Dermatologists. Guidelines for treatment of onychomycosis. Br J Dermatol. 2003;148:402-10.

45. Van Duyn Graham L, Elewski BE. Recent updates in oral terbinafine: its use in onychomycosis and tinea capitis in the US. Mycoses. 2011;54:e679-85.

46. Lubeck DP, Gause D, Schein JR, Prebil LE, Potter LP. A health-related quality of life measure for use in patients with onychomycosis: a validation study. Qual Life Res. 1999;8:121-9.

47. Gupta AK, Simpson FC. New therapeutic options for onychomycosis. Expert Opin Pharmacother. 2012:13:1131-42.

48. Longhini R, Raksa SM, Oliveira ACP, Svidzinski TIE, Franco SL. Obtenção de extratos de própolis sob diferentes condições e avaliação de sua atividade antifúngica. Rev Bras Farmacogn. 2007;17:388-95.

49. Sotiriou E, Koussidou-Eremonti T, Chaidemenos G, Apalla Z, Ioannides D. Photodynamic therapy for distal and lateral subungual toenail onychomycosis caused by Trichophyton rubrum: Preliminary results of a single-centre open trial. Acta Derm Venereol. 2010;90:216-7.

50. Hochman LG. Laser treatment of onychomycosis using a novel 0.65 -millisecond pulsed Nd:YAG 1064-nm laser. J Cosmet Laser Ther. 2011;13:2-5.
MAILING ADDRESS:
Maria Fernanda Reis Gavazzoni Dias
Rua Mariz e barros, 176 salas 607 e 608
Icaraí
24220-121 Niterói, RJ.
Brazil
Email:mgavazzoni@gmail.com

How to cite this article: Dias MFRG, Quaresma-Santos MVP, Bernardes-Filho F, Amorim AGF, Schechtman RC, Azulay DR. Therapeutic update on superficial mycoses: review article part I. An Bras Dermatol. 2013;88(5):764-74. 